\title{
Risk Perception and the Financial System
}

\author{
Lynnette D. Purda \\ Queen's University \\ Kingston, Ontario Canada
}

\footnotetext{
${ }^{1}$ Queen's School of Business, Queen's University, Kingston, Ontario Canada K7L 3N6. Phone: (613) 5336980 Fax: (613) 533-2321. Email: lpurda@business.queensu.ca. Helpful comments were provided by Richard Cantor, Tina Dacin, Art Durnev, Lorraine Eden (IPE Departmental Editor), Adair Morse, Eric Santor, three anonymous referees, and seminar participants at the Bank of Canada and Northern Finance Association annual meetings. Funding for this project was provided by the Social Sciences and Humanities Research Council of Canada.
} 


\title{
Risk Perception and the Financial System
}

\begin{abstract}
I examine how a country's financial system influences assessments of firm-level risk. Consistent with theories of financial intermediation, I hypothesize that firms located in a country with a bank-oriented financial system will be perceived as posing a lower credit risk than otherwise similar firms in a market-oriented setting. Banks have long been suggested to be effective monitors of managerial behavior and their relationships with clients put them in a position to renegotiate credit agreements at early signs of financial distress. Using a unique database of firm-level credit ratings from 8 different countries, I find strong evidence that lower risk assessments are provided for firms in bank-based systems. Even after considering elements of a country's legal infrastructure that relate to creditor protection and insolvency proceedings, the financial system remains an important determinant of credit rating assignment. The results are also robust to the inclusion of several firm-level controls including financial performance, industry, ownership concentration, political connections, and the ease with which the firm's assets can be monitored.
\end{abstract}




\section{Risk Perception and the Financial System}

\section{Introduction}

International business research has a long history of documenting that a country's institutional infrastructure can impact how its risk is perceived by investors. These investors may be multinational companies considering direct investment in the country or, equally important, financial investors deciding whether to inject capital into a nation's financial system. Financial investors are primarily concerned with the risk that borrowed funds will not be repaid. As a result, specialized measures of country risk have been developed to measure the creditworthiness of borrowing nations. Using a variety of these credit assessments, research by Cossett and Roy (1991), Vaaler, Schrange, and Block (2005) and Butler and Fauver (2006) has concluded that a country's perceived credit risk is impacted by factors such as political risk, macroeconomic conditions, and monetary policy.

I advance this stream of research by moving from assessments of country risk to perceptions of firm-level creditworthiness. In this context, I examine how a country's financial infrastructure influences these perceptions. Drawing on a large body of theory and evidence outlining the role of financial intermediaries, I hypothesize that a firm's perceived credit risk will be influenced by whether it is located in a country with a bank or market-oriented financial system. In bank-based systems, firms receive the bulk of their external funding through financial intermediaries whereas firms in market-oriented systems arrange most of their financing through the public bond and stock markets. I believe that differences in a country's financial infrastructure influence independent assessments of firm-level credit risk in a systematic way. Specifically, I hypothesize that firms in bank-based systems are perceived to pose less risk than otherwise similar firms located in market-oriented environments.

The underlying rationale for the hypothesis is based on two characteristics of bank-based systems. First, bank debt has been suggested to represent inside debt (Fama, 1985 ) in the sense that a firm's close and specialized relationship with its bankers allows for the exchange of non-public information. Access to this information allows the bank to carefully monitor firm management and scrutinize its behaviour to ensure that 
management acts in the best interest of investors. This additional monitoring is not possible with arms-length transactions such as public bond issues. The informed nature of bank debt leads to a second potential risk-reducing feature of bank-oriented financial systems. Careful monitoring by banks makes them aware of repayment problems at an early stage, giving lenders the opportunity to informally renegotiate credit terms rather than rely on formal bankruptcy and insolvency procedures. The negotiation process is facilitated by the small number of lenders involved. As opposed to bond market issues that may involve hundreds or thousands of individual investors, bank debt will involve only the lead bank and banks within the lending syndicate. An enhanced ability to renegotiate may reduce the risk of loss from a firm in financial distress since lenders are generally able to recover a greater proportion of borrowed funds through renegotiation than formal liquidation.

To test the hypothesis I use credit ratings from Moody's Investors Services (Moody's) to proxy for investors' perception of firm-level credit risk. Using a unique, cross-country database provided by Moody's, I examine issuer-level credit ratings for firms from eight different countries during the years 1993 to 2001. Moody's is the largest provider of credit ratings world-wide. As of 2007, the company provided credit opinions for \$85US trillion worth of outstanding debt issued by more than 150,000 borrowers from over 100 countries.

Countries that are similar in maintaining a strong bank orientation may share additional features that influence perceptions of credit risk. In particular, countries with a bank-based system will have a legal environment consistent with this system. Since lending arrangements are frequently governed by contract law and formal bankruptcy proceedings administered by the courts, legal environment is a likely influence of perceived credit risk. The empirical tests consider this possibility, using various proxies to control for the efficiency of a country's insolvency regime and creditors' rights. The principle finding persists. Financial system remains an important determinant of credit rating even after controlling for legal environment.

The results are also robust to the inclusion of several firm-level characteristics that may influence credit risk. These include financial performance, industry, and variables which have been linked to corporate governance problems such as ownership 
concentration and political connections. I also consider the ease with which a firm's assets can be monitored since this will influence the comparative advantage a bank holds over other investors. If a firm's assets are predominately tangible and easily observed, bank knowledge may closely resemble that of the general public and have little influence on risk perception.

I provide two significant contributions to the literature on firm-level perceptions of risk. First, I find significant support for the hypothesis and document that firms based in bank-oriented financial systems receive better credit ratings than similar firms located in market-based economies. In general, these firms are perceived as posing less credit risk despite using a greater proportion of debt to fund their operations. This result is remarkably robust. It persists regardless of the proxy for bank-based versus marketoriented systems and with the inclusion of several firm-level controls. Second, I find that country-level variables indicative of legal protection for creditors are not significant influences of perceived credit risk once we control for the type of financial system in place. I conjecture that this may be because banks rely more heavily on informal negotiations with distressed borrowers than formal legal proceedings.

The remainder of the paper proceeds as follows. The next section provides theory and evidence related to banks' role as financial intermediaries and their influence on perceptions of firm-level credit risk. This is followed by a discussion of the empirical setting including differences in the characteristics of bank and market-oriented financial systems and the role of credit ratings in an international context. The hypothesis follows naturally from the conceptual framework provided by combining theories of financial intermediation to this empirical setting. The methodology and empirical specification are then presented. Results and robustness tests, including the addition of variables controlling for a country's legal environment follow. Finally, I conclude with a discussion of the contributions of the research, its limitations, and possible extensions.

\section{Theories of Financial Intermediation and the Role of Banks}

Leland and Pyle (1977) and Diamond (1984) were among the first to suggest that financial intermediaries develop out of a need to reduce information asymmetries between borrowers and lenders. They rationalized that since borrowers know more about 
the true value of their projects than lenders their behaviour must be carefully monitored to ensure that they abstain from acting in their own self interest. To avoid the duplication of effort among many small investors or a free-rider problem in which information produced by the resources of one investor becomes freely available to others, a financial intermediary can be delegated to undertake the task of monitoring the actions of the borrowing firm. This monitoring requires an investment of time and resources. If there are economies of scale or unique skills that develop to allow information production and monitoring to be conducted at reduced cost then specialized institutions will evolve to undertake these activities.

Banks represent the most frequently studied form of financial intermediary. Evidence has shown that investors use the observable actions of banks to influence their own risk perceptions and correspondingly their investment behaviour. For instance, James (1987) showed that the willingness of a bank to supply funds is viewed by equity holders as a sign that private information shared between the firm and its banker is positive. As a result, stock prices increase in response to the announcement of new banking relationships and decrease when relationships are terminated. Irvine and Rosenfeld's results (2000) confirm the decline in share price when bank debt is eliminated and establish that the decline is particularly severe for firms of low credit quality where monitoring by a financial intermediary is most valuable. Similarly Fields, Fraser, Berry and Byers (2006) document that bank relationships are more valuable to smaller firms, firms with poor financial performance, or during periods when the economic credit risk is high.

Bank debt may even be structured differently when there is concern that the risk of default is significant. Lee and Mullineaux (2004) find that the composition of lending syndicates varies in an intuitive way with the degree of monitoring that is required. Syndicates are smaller and more concentrated when there is little information about the borrower and credit risk is high. This also suggests that syndicates are structured to facilitate possible future renegotiations in these cases. 


\section{Empirical Setting}

Bank versus Market-Oriented Financial Systems

An extensive literature exists comparing the features of bank versus market oriented financial systems (Allen and Gale, 1999; Rajan and Zingales, 2001; Booth et al, 2006) and the impact of financial system development on a country's economic growth (King and Levine, 1993; Rajan and Zingales, 1998). Despite this literature, there is limited evidence that one type of system dominates the other (Beck and Levine, 2002; Demirgüç-Kunt and Maksimovic, 2002) which perhaps explains the persistence of these two financial systems today.

The distinguishing feature between the two types of systems is the extent to which firms rely on banks for their financing versus public markets. According to Baliga and Polak (2004) this changes the kind of commitment provided by the lender and forces them to trade-off monitoring versus liquidity. Taking a historical perspective, they suggest that the existence of fewer but larger firms during the German industrial revolution provided banks with large enough loans to make costly monitoring worthwhile whereas the larger number of small firms present during the British industrial revolution prompted bankers to prefer the liquidity provided by a number of small loans rather than continuous monitoring.

Perhaps the most common explanation for whether a country maintains a bank or market oriented financial system stems from the work of La Porta, Lopez-de-Silanes, Shleifer and Vishny $(1997,1998)$. These researchers, hereafter LLSV, show that characteristics of a country's legal environment influence the development of its financial markets. In particular, common law countries tend to advocate greater property rights and provide more protection for minority shareholders than civil law countries. As a result, arms-length transactions are more prevalent in common law countries and stock markets are larger. When legal standards are weaker and contract enforcement is poor, banks are argued to provide the dominant source of finance since their greater monitoring abilities can compensate for insufficiencies in the legal environment (Boot and Thakor, 1997; Rajan and Zingales, 1998; Ergungor, 2004). 
My approach mirrors that of Demirgüç-Kunt and Maksimovic (2002) in allowing for the influence of both the financial system and elements of the legal environment. While I hypothesize that features of bank-based systems may lead investors to have lower perceptions of firm-level credit risk, I recognize that so too may laws that are strongly supportive of creditor rights. Therefore I examine the influence of the financial system on rating assignments while controlling for elements of the legal environment related to creditor rights and bankruptcy proceedings. I conduct several robustness tests to ensure that the results are not unduly influenced by a relationship between financial system type and legal characteristics, testing for multicollinearity and making use of alternative measures for both factors. ${ }^{1}$

\section{Credit Ratings in an International Context}

Survey evidence from American and European managers suggests that credit ratings are important influences on a firm's capital structure decisions (Graham and Harvey, 2001; Bancel and Mittoo, 2004). Not only do ratings influence the cost at which debt can be obtained (Ederington, Yawitz, and Roberts, 1987 ) they also impact management's decision on whether or not debt should be issued at all (Kisgen, 2006). In an international context, credit ratings may also determine the source of debt, in particular whether it is issued locally or abroad. Anecdotal evidence from the business press suggests that the recent establishment of several local rating agencies has done little to weaken the influence of rating opinions provided by the dominant US-based firms and that "...for big international issuers of debt there is little choice...for many investors the imprint of S\&P or Moody's will drive decisions for a long time to come." this is due in part to the importance that US institutional investors place on these ratings, particularly since they are designated as "Nationally Recognized Statistical Rating Organizations" and therefore frequently referred to in regulations and portfolio guidelines (Cantor and Packer, 1994; McNamara and Vaaler, 2000).

This study makes use of a novel database provided by Moody's. While historical credit rating data is readily available for American firms on standard financial databases such as Compustat, cross-country rating data is much more difficult to obtain. The data used here allows for the examination of credit ratings across a much larger range of countries than most previous studies. The countries focused on are relatively homogenous 
in terms of their economic development and Moody's ratings are common for firms in these countries during the sample period.

A Moody's credit rating is a function of two factors: 1) the probability of default and 2) the severity of loss that a creditor faces if default occurs (Moody's, 2000). Both of these factors may be influenced by the characteristics of the country in which a firm resides. For example the likelihood of default may depend on the probability of receiving assistance from the government, suppliers, or the labour force when the first signs of financial distress appear. The severity of loss will depend on the country's insolvency regime, particularly whether it is oriented towards liquidation or rehabilitation since recovery rates tend to be higher when the firm is treated as a going concern (Moodys, 2006).

As Moody's has expanded its operations abroad, it has been faced with the challenge of accommodating country-specific factors while maintaining global consistency of ratings. Moody's Credit Policy Committee (CPC) is responsible for meeting this challenge stating that "the role of the CPC is to ensure broad consistency in our rating methodologies and overall practices." "3 Moody's is careful to point out that consistency in rating meaning does not necessarily imply consistency in rating determinants. Elaborating on this point, the company states that "...for ratings to be consistent across regions they should share a common conceptual framework - common meanings and common potential drivers - but the application of that framework is likely to be quite different in response to local market circumstances." ${ }^{4}$ This implies that ratings may show systematic differences across countries. For example, firms in one country may pose the same level of risk as firms in another, even at systematically higher leverage levels, if the countries have markedly different insolvency procedures.

One of the most important country factors to consider is the reliance on informal renegotiations in the event of financial distress versus formal court procedures. Moody's is well aware of discrepancies in this area. For example, a report issued in March of 2000 comparing insolvency regimes across France, Germany and the UK indicated that:

In the UK, debtors are encouraged to seek remedies at an early stage (prior to formal proceedings) given the limited nature of formal restructuring procedures 
such as the ones existing in the US and Germany. Similarly, debtors in France can also restructure without involvement of the courts... ${ }^{5}$

Differences in the reliance on formal laws and regulations will impact the role that a country's legal environment has on perceived credit risk. If informal negotiations dominate formal procedures then a country's official laws related to debt contracts may not be a significant influence of ratings. Credit ratings may instead be more greatly influenced by the likelihood that these negotiations will take place.

\section{Hypothesis Development and Data Description}

The hypothesis follows naturally from theories of financial intermediation applied to the empirical setting. Banking relationships provide effective monitoring of managerial behaviour and this monitoring serves to reduce the probability of default. In addition, since bank debt represents informed debt (Fama, 1985) and a smaller number of players are involved than in public market transactions, negotiations can take place at the first signs of financial distress, thereby reducing the severity of loss. These features of banking relationships result in the formal hypothesis: firms located in bank-based financial systems will receive better credit ratings than otherwise similar firms located in market-based systems.

To be part of the sample which will be used to test the hypothesis, a firm must be included in the ratings data provided by Moody's and have available financial information in the Global Vantage database. In addition, the legal characteristics of the firm's country must be described in the work of $\operatorname{LLSV}(1997,98)$.

These requirements result in a database including firms from eight different countries, specifically Canada, France, Germany, Japan, New Zealand, the Netherlands, the United Kingdom and the USA. The sample period begins in 1993, the first year I have access to Global Vantage data and ends in 2001. I examine credit ratings at each calendar year-end, resulting in a pooled panel dataset. A single firm may represent multiple observations in the sample if it maintains a rating for more than one year. The empirical tests provide robust standard errors that do not require independence among observations from the same firm. 
The country with the largest number of observations in the sample is the USA followed by Japan. Almost three quarters of the observations are from market-based financial systems. This should come as no surprise given that the Global Vantage database selects firms based on their inclusion within large international or local market stock indices ${ }^{6}$ and stock markets will be larger in financial systems that are marketoriented. This requirement, along with the fact that all of the firms maintain credit ratings, implies that these firms are not necessarily representative of the average firm in their home country. Foreign firms issuing public debt requiring a US-based credit rating are likely much larger and more mature than their national counterparts.

Table 1 provides a first look at the data. Panel A provides median summary statistics by country for the six countries in our sample with more than 40 observations (New Zealand and the Netherlands are excluded). Median levels of reported total debt to capital, interest coverage, and return on assets are provided. ${ }^{7}$ Consistent with previous literature examining international differences in capital structure (Borio, 1990; Chui, Lloyd and Kwok, 2002) the sample firms from continental Europe and Japan report higher leverage levels than firms from North America and the UK. Since France, Germany and Japan all maintain bank-oriented financial systems according to the classifications provided by Demirgüç -Kunt and Levine (1999) Panel B of the table presents median values for various financial characteristics of the sample firms when they are categorized as belonging to either bank or market-based systems. Column three provides test statistics as to whether the median values differ significantly across the two categories. The statistics are chi-squared statistics resulting from a nonparametric test of the equivalence of medians across the two sub-samples.

From the table we see that the sample firms in bank-based financial systems tend to be larger and less profitable than firms in the market-based sub-sample. While the median long term debt to total capital is similar across the two sub-samples the total debt to capital is much larger for the bank-based group consistent with Desai, Foley and Hines' (2004) observation that firms are more highly levered when the supply of local credit is large. This higher leverage level translates to lower interest coverage but surprisingly does not correspond to lower ratings. The median rating is higher for the bank-oriented sub-sample than the market sub-sample. 
Table 2 provides summary financial statistics when the sample observations are categorized according to Moody's ratings. These ratings range from the best possible rating of Aaa to the worst rating in our sample, B. The first column of the table shows that firms that are perceived to pose less credit risk (ie are assigned better ratings) are larger and maintain better interest coverage than firms with poor ratings. In addition, the general trend is for well-rated firms to have lower leverage and higher return on assets.

Columns two and three of the table again divide the sample into firms from market and bank based systems. Here we see that for the best rating categories there is a significant difference in leverage levels for firms in bank versus market-based environments. For both long term and total debt ratios, firms from bank-based systems are much more highly levered than firms from market-oriented systems in the Aaa and Aa rating categories. Higher leverage for these firms also translates into significantly lower interest coverage. In addition, firms from bank-based countries have a lower median return on assets than their counterparts in market-based firms in five of the six rating categories. These observations provide us with our first insights into systematic differences in rating assignments across the two types of financial systems.

\section{Methodology and Empirical Specification}

\section{Ordered Probit Model}

To test the hypothesis I model the decision process undertaken by Moody's when determining a firm's credit rating. Although this process is unobservable to the public, we witness its outcome, namely the credit ratings that are ultimately assigned. Due to the ordinal nature of credit ratings, I use an ordered probit model to map this unobservable process into ratings as in Blume, Lim, and MacKinlay (1998), Bhojraj and Sengupta (2003) and Purda (2007).

The rating assigned to firm $i$ in a given year $t$ acts as the dependent variable in the model and is denoted by Rate $_{i}$. This variable can take on one of 6 values with 6 referring to the rating Aaa and 1 referring to $B$. The full rating spectrum from best to worst credit quality corresponds to the dependent variable in the model in the following way: 


\begin{tabular}{c|c} 
Rating Assignment & $\begin{array}{c}\text { Corresponding Dependent } \\
\text { Variable Value (Rate }\end{array}$ it $)$ \\
\hline Lowest Credit Risk & 6 \\
Aaa & 5 \\
Aa & 4 \\
A & 3 \\
Baa & 2 \\
Ba & 1 \\
B & \\
\hline
\end{tabular}

The ordered probit model allows us to establish whether a particular firm or country characteristic is an important influence on the assigned rating. These characteristics act as the independent variables and the model produces a set of estimated coefficients relating these independent variables to the rating assignment. ${ }^{8}$ The independent variables of primary interest are those proxying for a country's financial system but a group of control variables that have previously been shown to be related to credit ratings are also included. In addition, since it is possible that a country's legal environment as it relates to debt contracts will also influence perceptions of credit risk, I include variables indicative of the country's respect for property rights, creditor protection and overall judicial effectiveness. Finally, for robustness I control for factors that may influence how easily a firm may be monitored, namely the tangibility of its assets, in addition to possible indicators of governance problems.

\section{Proxies for Financial System and Legal Environment}

The primary variables related to the hypothesis proxy for a country's financial system. Relying on the classification provided by Demirgüç-Kunt and Levine (1999) I generate a dummy variable that takes on the value of 1 for countries with a bank-oriented financial system and 0 for nations with a market-based system. According to this classification, France, Germany, Japan and New Zealand have bank-based financial systems while Canada, the Netherlands, United Kingdom and United States are marketoriented.

For robustness, I introduce alternative proxies for financial system derived from data provided by the International Monetary Fund (IMF). The first proxy is the value of 
domestic credit provided by a country's banks scaled by the nation's GDP. Unlike the simple classification of countries into bank or market systems, this measure is timevarying, consistent with the pooled panel structure of the data. I expect that domestic credit will represent a significantly larger proportion of GDP in bank-oriented economies. In addition to this proxy, I include a measure of a country's stock market capitalization, again as a proportion of GDP. This measure should be higher in countries with a market orientation.

Characteristics of the countries' legal environment that reflect attitudes towards debt repayment are taken from two sources. The first source is the frequently cited work of LLSV (1998). The second source is the Economist Intelligence Unit which is associated with The Economist magazine.

Choosing variables most closely related to the protection of lenders, I generate two variables from LLSV. The first is an aggregate measure of the legal environment's respect for property rights and the second a specific measure of creditor protection. The property rights measure follows Morck, Yeung, and Yu (2000) and combines LLSV's measures of the level of corruption within a country, the risk of expropriation of private property, and the likeliness of contract repudiation. Each of these three indices can take on a value from 1 to 10 resulting in a maximum value of 30 for the aggregate property rights variable. Larger values for this measure correspond to a greater respect for private property. The creditor protection variable ranges from 0 to 4 with 4 indicating a high level of protection for lenders' interests if bankruptcy occurs. ${ }^{9}$

The Economist Intelligence Unit's database of market indicators provides two variables which may be associated with the legal system's treatment of creditors when a firm faces financial distress. The first of these variables is labeled Institutional Effectiveness and although it represents a country's infrastructure across many dimensions, it incorporates an assessment of a country's financial risks, government effectiveness, and legal/regulatory environment. Countries can be awarded a maximum value of 10 for this measure. The second variable, which can take on a maximum value of 5, is titled Judicial Transparency and reflects the fairness of the judicial process, unfair competitive practices, price controls, and the integrity of accounting practices. These two measures are time-varying although the data reveals significant persistence. Measures for 
a particular country change very little from year to year. The Economist variables are much broader in their scope than the factors taken from LLSV and provide a more general view of a country's legal and institutional infrastructure.

Panel A of Table 3 summarizes the financial system and legal variables across the sample countries. For variables that are time-varying I provide the value for 1998 which is near the mid-point of the sample. It is clear from this summary that countries classified as having bank-oriented financial systems do in fact have significantly larger values of domestic credit provided by banks and smaller stock market capitalizations. At first glance, it is difficult to see any particular pattern for the legal variables and so Panel B of the table presents the pairwise correlations among all seven country variables. For the three financial system proxies, the correlations are as expected with domestic credit and the financial system dummy showing significant and positive correlation with one another and negative correlation with stock market capitalization. The four characteristics of the legal environment are all significantly correlated with one another. Countries that score well on the property rights and creditor protection indices maintain high levels of institutional effectiveness and judicial transparency.

Panel B also shows the extent to which countries that share a financial system orientation maintain similar legal characteristics. Surprisingly, the level of creditor protection within a country shows no significant relationship to the financial system orientation of our sample countries. It is not the case that bank-based systems with significant domestic lending maintain a legal infrastructure strongly supportive of the rights of creditors. Similarly, the property-rights index shows no significant correlation with financial system orientation. ${ }^{10}$

\section{Primary Control Variables}

I control for firm-level factors that are likely to influence Moody's rating assignments. Most paramount among these are indicators of a firm's financial performance. Drawing on a large literature relating financial statement variables to credit ratings (Kaplan and Urwitz, 1979; Ederington, Yawitz, and Roberts, 1987; Blume, Lim and MacKinlay, 1998) I include long term debt to total capital, total debt to total capital, interest coverage, return on assets (ROA), and market capitalization. Leverage and return 
on asset variables are presented in percentage form. For example ROA is calculated as net income divided by total assets multiplied by 100 . Interest coverage is defined as the sum of operating income after depreciation plus interest expense divided by interest expense. Following Blume et al (1998) I adjust this measure in several ways to reflect the fact that an improvement in coverage may be more meaningful if the initial coverage level is low. Four individual coverage variables are defined to represent coverage in the range of 0 to 5 times, 5 to 10,10 to 20 , and 20 to 100. Ratings are expected to be related most strongly to interest coverage when this ratio falls within the first range from 0 to 5 . Since additional coverage beyond a certain level may be meaningless, ratios in excess of 100 are set equal to 100 . All negative coverage ratios are set to 0 . Market capitalization is measured in $\ln$ form and all financial statement variables are downloaded from the Global Vantage database.

In addition to financial performance, I control for the firm's industry using the classification system provided by Campbell (1996). This system translates 2 digit SIC codes into 13 industry categories. ${ }^{11}$ Dummy variables are created to correspond to each industry category. I also control for the year of the observation since evidence suggests that the rating process is not entirely stable over time. Altman (1998) documented an increase in the number of downgrades relative to upgrades while Blume et al (1998) established that the standards of rating agencies have become increasingly stringent in recent years. As a result, I create a variable called Year which takes on a value of 0 in 1993, the first year of the sample, and increases by 1 for every subsequent year. Results are similar when year dummies were used in place of this variable.

\section{Empirical Results}

Table 4 reports results related to the hypothesis on the financial system's influence on perceptions of firm-level credit risk. The first column provides a base case model establishing the relationship between ratings and the financial, industry, and year controls. ${ }^{12}$ Coefficients are mainly as expected. Larger firms with less long term debt and adequate interest coverage receive better ratings. Consistent with Blume et al (1998), the Year variable is negatively related to rating assignment indicating more stringent standards for rating agencies over time. 
The second column of Table 4 introduces the financial system dummy indicating whether a country maintains a bank or market orientation. The estimate coefficient is strongly positive indicating that firms in bank-based systems receive better ratings than similar firms located in market-oriented settings. This is consistent with the hypothesis that bank relationships serve to lower the perceived credit risk of individual firms.

To get an idea of how meaningful this result is and have a better sense of the impact that being in a bank-oriented environment has on a firm's rating assignment I examine the marginal effect of the financial system dummy. I focus on the rating assignment " $A$ " since it is the most common rating in the sample. Suppose that the characteristics of a particular observation are equal to the mean values of all the independent variables and that the firm is located in a market oriented environment. The estimated ordered probit model calculates the probability of this firm being assigned a rating of A to be approximately $27.35 \%$. Keeping everything else equal but placing the firm in a bank-oriented financial system increases the probability of this rating assignment by $12.35 \%$ so that the predicted probability of an A rating climbs to $39.70 \%$.

The inclusion of the financial system dummy does not eliminate the control variables' relationships with the dependent variable, Rate $_{i t}$. Firm size and interest coverage are still seen to be positively related to credit rating while long term debt and year maintain their significant negative influences.

To ensure that the result is related to financial system orientation rather than some other characteristic proxied by the financial system dummy, columns three and four of the table introduce alternative measures of bank influence. Column three replaces the financial system dummy with the measure of domestic credit provided by banks as a proportion of the country's GDP. Column four incorporates both the domestic credit variable and measure of stock market capitalization.

The results are confirmed in each model specification. Column three shows that the greater a country's domestic credit to GDP ratio, the more favorably its firms' credit risk is perceived. As in column two, this relationship persists even after controlling for financial performance, industry, and year. Coefficient estimates for these controls are similar in the sense that long term debt, interest coverage, firm size and year remain significant determinants of credit rating. The addition of the stock market capitalization 
measure in column four does not eliminate this result. Firms in bank-oriented systems continue to receive better credit ratings.

\section{Controlling for Legal Environment}

The greatest robustness challenge to the results is the suggestion that it is not the financial system that influences perceptions of credit risk in and of itself but some underlying characteristic that bank-oriented economies have in common. The legal environment, as it relates to the protection of creditors and the efficiency of a country's bankruptcy procedures is a worthy challenger since previous research has shown its influence on the interest rate at which debt can be issued (Bae and Goyal, 2007).

Table 5 provides the results for the examination of legal factors with the first column specifying a model incorporating the two LLSV variables reflecting respect for property rights and creditor protection. I refrain from introducing the financial system indicator in this base-case model to see the influence of these legal factors on rating assignment when financial performance, industry and year serve as the only controls. The estimated coefficients on both variables are positive in that higher levels for creditor protection and property rights are consistent with better credit rating assignments. However, only the creditor protection coefficient is statistically significant.

When financial system orientation is ignored, creditor protection seems to significantly influence perceptions of firm-level risk. The results change however when the financial system indicator is introduced in column 2. Under this specification of the model, the bank-orientation dummy variable is again highly significant while the creditor protection variable is no longer a meaningful determinant of credit ratings.

Although the pairwise correlations presented in Table 3 showed little relation between the LLSV legal variables and financial system dummy in the sample, I check whether the decline in significance of the creditor protection index is the result of multicollinearity among country characteristics. I do so by running a linear regression with the same independent and dependent variables as in column 2. Although strictly speaking ordinary least squares regression is not appropriate in cases with an ordered categorical dependent variable such as Rate $_{i t}$ it allows for the calculation of variance inflation factors to establish the extent to which multicollinearity is a problem. 
Calculation of these factors shows no evidence that the results are compromised by correlations among the independent variables. As a result, I conclude that banking relationships are more influential than formal legal mechanisms for creditor protection in Moody's assessment of credit risk. I suggest that banks' ability to informally renegotiate credit terms with distressed firms allows for a reduction in perceived credit risk even in environments in which formal laws related to insolvency are weak.

As a final robustness check, I include the more general variables reflecting quality of the legal environment taken from the Economist Intelligence Unit. Neither Institutional Effectiveness nor Judicial Transparency are significant influences of credit rating despite the fact that their estimated coefficients are both positive. Including these variables in the model does not alter the significance of the financial system indicator and I again conclude that firms in bank-based systems receive better credit ratings.

\section{Robustness Checks: Inclusion of Additional Firm-level Characteristics}

While a wide range of factors may be incorporated into a rating agency's assessment of credit risk I focus on additional firm-level characteristics that may reduce the advantages provided by strong banking relationships. The first set of characteristics reflects the ease with which a firm's true value can be assessed. As in Durnev and Kim (2005) I suggest that firms with a greater proportion of tangible assets are easier to monitor and as a result, the advantages provided by additional bank monitoring may be reduced. I therefore introduce two measures of tangibility, the proportion of a firm's assets that are represented by property plant and equipment (PP\&E) and its level of spending on research and development (R\&D) also scaled by assets. I suggest that better credit ratings will be assigned to firms that are easier for credit rating agencies to monitor because they are composed largely of hard assets (high PP\&E and low R\&D). Tangible assets can also be posted as collateral to ensure a higher recovery rate in case of default.

I incorporate PP\&E and R\&D into the ordered probit model representing the rating decision to establish whether they eliminate the significance of the financial system dummy. Table 6 presents the results. The first column repeats the model with the bankoriented indicator from Table 4 for ease of comparison. The second column includes the measure of the firm's PP\&E and the third column also incorporates the R\&D variable. 
The number of observations declines significantly in column three due to the large number of missing observations for R\&D in the Global Vantage database.

The tangibility of a firm's assets influences risk perception as expected. Firms with more tangible assets are viewed to pose less credit risk than otherwise similar firms. The PP\&E variable shows a strong positive influence on rating assignment that persists even when $R \& D$ is included. The greater the level of $R \& D$ spending the lower the credit rating consistent with the difficult nature of assessing the true value of $R \& D$. Despite the significance of these variables and their impact on credit rating assignment, the financial system dummy remains important. Firms in bank-based systems are still assigned better ratings even after controlling for the ease of monitoring.

The final set of firm-level characteristics that I incorporate reflect potential corporate governance problems suggested by the firm's proportion of inside ownership and political connections. Research suggests that the view of a firm as a widely held entity with numerous small shareholders is not universally applicable and that a significant number of firms in a variety of countries are in fact closely held (La Porta, Lopez-de-Silanes and Shleifer 1999; Classens, Djankov, and Lang, 2000; Faccio and Lang, 2002). Concentration of ownership raises the possibility that large shareholders will represent their own interests, particularly when these shareholders are also management. While inside ownership has been suggested to align the interests of management and investors and reduce principal agent problems, Stulz (1988) argues that after a certain level, increases in inside ownership will only serve to further entrench management. As management becomes more entrenched they will be more likely to act in their own self-interest and negatively impact firm value. Morck, Shleifer and Vishny (1988) and Claessens, Djankov, Fan and Lang (2002) provide empirical evidence consistent with this entrenchment effect. As a result, I speculate that inside ownership may negatively influence credit rating assignment and control for the proportion of closely held shares for the sample firms as provided by the Worldscope database.

Political connections introduce additional governance concerns that may influence a firm's perceived credit risk. Ex ante, it is unclear whether this impact is positive or negative. For instance firms with political connections may receive significant benefits such as preferential treatment when bidding for government contracts or financial support 
in times of distress. Alternatively, preferential treatment may be indicative of a country's corruption level thereby negatively influencing perceived risk.

I identify firms as having a political connection by using the data provided by Faccio (2004). Faccio assembles a database of firms from across 47 different countries and categorizes them as being politically connected if at least one of their large shareholders or top management is a member of parliament, a minister or closely related to a top politician or party.

Results for the inclusion of these governance variables are presented in column four of Table 6. Firms with a greater proportion of closely held shares are assigned lower credit ratings, consistent with inside ownership resulting in managerial entrenchment problems. A firm's political connections have no significant influence on rating assignment. Again we see that the principle findings are remarkably robust. The inclusion of these variables does little to reduce the significance of the financial system indicator.

\section{Discussion and Conclusions}

The major question that was address in this paper was whether the financial system influences perceptions of firm-level credit risk evidenced by Moody's credit ratings. Drawing on theories of financial intermediation, I suggested that monitoring by banks helps to ensure that management acts in investors' best interests, that financial distress is identified in early stages, and that renegotiation of credit terms is facilitated. Together, these factors led to the hypothesis that Moody's may perceive firms located in bank-based financial systems to pose a lower credit risk than otherwise similar firms located in market-based economies.

Using a database of Moody's ratings from eight different countries I modeled the rating assignment decision using an ordered probit model and found significant support for the hypothesis. Firms in bank-based systems received better ratings even after controlling for financial performance, industry, and the year of observation. The results are remarkably robust, persistent to the use of various proxies for financial system, the incorporation of variables reflecting a country's legal environment, and the inclusion of additional firm characteristics related to asset tangibility and governance concerns. Legal factors are insignificant influences on firm-level credit ratings consistent with the 
suggestion that informal renegotiation may be a more important determinant of perceived credit risk than formal legal procedures.

As with any research, this study suffers from potential limitations. The first is that the proprietary nature of credit ratings and the difficulty in obtaining historical ratings data across numerous countries forced me to rely on a single perception of credit risk, Moody's ratings. It is some consolation that ratings across agencies have previously been shown to be highly correlated. For instance Jewell and Livingston (1998) found that only $17 \%$ of bonds with ratings from both Moody's and S\&P were assigned different ratings by the two firms. I also suggest that focusing on a single rating agency may have some advantages since cross-country differences in ratings are more likely to reflect the agency's interpretation of the impact of country-specific factors rather than fundamental differences in rating methodology.

A second caveat to the research is that its future relevance will depend on changes in countries' insolvency regimes. A Moody's report from November $2006^{13}$ notes that recent years have seen a trend in European countries adopting insolvency codes with features similar to Chapter 11 from the US. As a result, bankruptcy regimes may be converging to the point where differences in country-specific regulations are minimal. A related concern is that our results assume that the relevant legal environment for a firm is that of its home country. This assumption may be overly simplistic in the case of multinational enterprises or even purely domestic firms that choose to raise funds abroad. Estimating the severity of loss for cross-border transactions may be complicated by the presence of multiple legal orientations and the willingness of courts in one jurisdiction to recognize insolvency officials from another.

A final caveat is that caution should be used in extending the results to the context of emerging markets. The empirical tests have been conducted on a set of observations from developed countries with well functioning financial markets. Credit ratings are in their infancy in emerging market economies and variation in legal characteristics across these countries is substantially greater than within the sample used here.

The findings have significant implications for management. Perhaps most importantly they suggest that firms in market-oriented environments may choose to implement additional mechanisms to improve their credit ratings. Consistent with 
findings from Klapper and Love (2004) and Durnev and Kim (2005) that firm-level corporate governance matters more in weak legal environments, I suggest that management may choose to compensate for the perceived increase in credit risk that being located in a market environment brings. Ways to compensate for this risk include agreeing to more restrictive debt covenants or posting additional collateral.

I have documented that firms in bank-oriented financial systems receive better credit ratings and suggested that the reduction in perceived credit risk stems from benefits provided by banking relationships. Whether these relationships can help to explain within-country differences in ratings is ultimately an empirical question. This suggests that a possible research extension would be to examine whether the proportion of debt financing that a firm receives from bank versus public markets impacts domestic credit rating assignments. 


\footnotetext{
${ }^{1}$ See Kwok and Tadesse (2006) and Beck, Demirguc-Kunt and Levine (2003) for discussions of the relationship between financial system and legal environment.

${ }^{2}$ The Economist, March 26, 2005 Volume 374, Issue 8419 page 69.

${ }^{3} \mathrm{http}: / /$ www.moodys.com/moodys/cust/loadBusLine.asp?busLineId $=300000000064$

${ }^{4}$ Measuring the Quality and Consistency of Corporate Ratings across Regions, Moody’s Special Comments, November 2004, page 9.

${ }^{5}$ Bankruptcy and Ratings: A Leveraged Finance Approach for Europe, Moody's Special Comment, March 2000 , page 4.

${ }^{6}$ See Rajan and Zingales (1995) for a detailed discussion of the Global Vantage database.

${ }^{7}$ Interest coverage is calculated as the sum of operating income after depreciation plus interest expense divided by interest expense. Leverage ratios and return on assets (ROA) are expressed in percentage terms. For example, ROA is measured by the ratio of net income to total assets multiplied by 100 .

${ }^{8}$ The ordered probit model also produces a second set of estimates. These estimates, frequently referred to as cut-off points, map the model's underlying unobservable process into the observable discrete outcomes that form the dependent variable. Here the unobserved process is the formation of the rating decision and the discrete outcome is the observable rating that is ultimately assigned. The cut-off points establish a range of values for the underlying process that correspond to the observed outcome. Since our focus is on the role of the dependent variables, I do not report estimates for the cut-off points in order to conserve space. These estimates are available upon request.

${ }^{9}$ I choose to control for more specific characteristics of a country's legal environment related to debt contracts rather than the country's legal origin, namely whether it has a common or civil law tradition. There are two reasons for this. First, it is consistent with previous research (see Morck, Yeung, and Yu, 2000 and Bae and Goyal, 2007 ) and second, studies that have examined a large cross-section of countries (rather than only eight nations as in our case) have found the tendency for countries with civil law origins to maintain bank-based financial systems. It has been argued that the underlying rationale for this is due to the greater respect for private property and minority shareholders found in common law countries (Demirguc-Kunt and Levine, 1999; Beck, Demirguc-Kunt and Levine, 2003).

${ }^{10}$ Panel B does not provide pairwise correlations among all of the independent variables used in the model. Clearly there are relationships among the financial controls. For instance, the ratios of long-term debt to capital and total debt to capital are related both to one another and to measures of interest coverage. The empirical results consider whether these relations introduce problems of multicollinearity. The calculation of variance inflation factors shows that multicollinearity does not unduly influence the results.

${ }^{11}$ The precise categories are petroleum, consumer durables, basic industry, food and tobacco, construction, capital goods, transportation, textiles and trade, services, leisure, unregulated utilities, regulated utilities, and financials. Our sample does not contain utilities.

${ }^{12}$ Coefficients are presented for the financial and year variables but are not reported for the 13 industry group dummy variables.

${ }^{13}$ Request for Comment on: Probability of Default Ratings and Loss Given Default Assessments for Corporate Obligors in Europe, Middle East and Africa: Recommended Framework, Moody's Rating Methodology, November 2006.
} 


\section{References}

Allen, F. and D. Gale, 1999. Comparing Financial Systems. MIT Press, Cambridge, MA. Altman, E. 1998. The importance and subtlety of credit rating migration. Journal of Banking and Finance 22, 1231-1247.

Baliga, S. and B. Polak, 2004. The emergence and persistence of the Anglo-Saxon and German financial systems. Review of Financial Studies 17, 129-163.

Bae, K. and V. Goyal, 2006. Creditor rights, enforcement and costs of loan finance. Queen's University and Hong Kong University of Science and Technology working paper.

Bancel, F. and U. Mittoo, 2004. Cross-country determinants of capital structure choise: A survey of European firms, Financial Management 33, 103-132.

Beck, T. Demirgüç-Kunt, A. and R. Levine, 2003. Law, endowments and finance. Journal of Financial Economics 70, 137-181.

Beck, T. and R. Levine, 2002. Industry growth and capital allocation: Does having a market- or bank-based system matter? Journal of Financial Economics 64, 147-180. Bhojraj, S. and P. Sengupta, 2003. Effect of corporate governance on bond ratings and yields: The role of institutional investors and outside directors. The Journal of Business $76,455-475$.

Blume, M., Lim, F. and A. MacKinlay, 1998. The declining credit quality of US corporate debt: Myth or reality? Journal of Finance 54, 1389-1413.

Booth, G., J. Junttila, J. Kallunki, M. Rahiala and P. Sahlstrom, 2006. How does the financial environment affect the stock market valuation of R\&D spending? Journal of Financial Intermediation 15, 197-214.

Boot, A. and A. Thakor, 1997. Financial system architecture. Review of Financial Studies 10, 693-733.

Borio, C. Leverage and financing of non-financial companies: An international perspective. Economic Papers 27, Bank for International Settlements.

Butler, A. and L. Fauver, 2006. Institutional environment and sovereign credit ratings. Financial Management 35, 53-79. 
Campbell, J., 1996. Understanding risk and return. Journal of Political Economy 104, 298 -345 .

Cantor, R. and F. Packer, 1994. The credit rating industry. Federal Reserve Bank of New York Quarterly Review (Summer-Fall).

Chui, A., Lloyd, A. and C. Kwok, 2002. The determination of capital structure: Is national culture a missing piece to the puzzle? Journal of International Business Studies 33, 99-127.

Classens, S., Djankov, S., Fan, J. and L. Lang, 2002. Disentangling the incentive and entrenchment effects of large shareholdings. Journal of Finance 57, 2741-2771.

Classens, S., Djankov, S. and L. Lang, 2000. The separation of ownership and control in East Asian corporations. Journal of Financial Economics 58, 81-112.

Cossett, J. and J. Roy, 1991. The determinants of country risk ratings. Journal of International Business Studies 22, 135-142.

Demirgüç-Kunt, A. and R. Levine, 1999. Financial structures across countries: stylized facts. Mimeograph, World Bank, Washington D.C.

Demirgüç-Kunt, A. and V. Maksimovic, 2002. Funding growth in bank-based and market-based financial systems: Evidence from firm-level data. Journal of Financial Economics 65, 337-363.

Desai, M., Foley, F., and J. Hines, 2004. A multinational perspective on capital structure choice and internal capital markets. Journal of Finance, 59 2451-2487.

Diamond, D., 1984. Financial intermediation and delegated monitoring. Review of Economic Studies 51, 393-414.

Durnev, A. and E. Kim, 2005. To steal or not to steal: Firm attributes, legal environment, and valuation. Journal of Finance 60, 1461-1493.

Ederington, L., Yawitz, J. and B. Roberts, 1987. The informational content of bond ratings. Journal of Financail Research 10, 211-226.

Ergungor, O., 2004. Market- vs. bank-based financial systems: Do rights and regulations really matter? Journal of Banking and Finance 28, 2869-2887.

Faccio, M. 2004. Politically connected Firms. American Economic Review 96, 369-386.

Faccio, M. and L. Lang, 2002. The ultimate ownership of western European corporations. Journal of Financial Economics 65, 365-395. 
Fama, E., 1985. What's different about banks? Journal of Monetary Economics 15, 2939.

Fields, L., Fraser, D., Berry, T. and S. Byers, 2006. Do bank loan relationships still matter? Journal of Money, Credit and Banking 38, 1195-1209.

Graham, J. and C. Harvey, 2001. The theory and practice of corporate finance: Evidence from the filed, Journal of Financial Economics 60, 187-243.

Irvine, P. and J. Rosenfeld, 2000. Raising capital using monthly income preferred stock: Market reaction and implications for capital structure theory. Financial Management 29, $5-20$

James, C. 1987. Some evidence on the uniqueness of bank loans. Journal of Financial Economics 19, 217-235.

Jewell, J. and M. Livingston, 1998. Split ratings, bond yields and underwriter spreads. Journal of Financial Research 21, 185-204.

Kaplan, R. and G. Urwitz, 1979. Statistical models of bond ratings: A methodological inquiry, Journal of Business 52, 231-61.

King, R. and R. Levine, 1993. Finance, entrepreneurship, and growth: theory and evidence. Journal of Monetary Economics 32, 513-542.

Kisgen, D. 2006. Credit ratings and capital structure. Journal of Finance 61, 1035-1072.

Klapper, L. and I. Love, 2004. Corporate governance, investor protection, and performance in emerging markets. Journal of Corporate Finance 10, 703-728.

Kwok, C. and S. Tadesse. National culture and financial systems. Journal of International Business Studies 2006, 227-247.

La Porta, R., Lopez-de-Silanes,F., Shleifer, A., and R. Vishny, 1997. Legal determinants of external finance. Journal of Finance 52, 1131-1150.

La Porta, R., Lopez-de-Silanes,F., Shleifer, A., and R. Vishny 1998. Law and finance. Journal of Political Economy 106, 1113-1155.

La Porta, R., Lopez-de-Silanes,F., and A. Shleifer 1999. Corporate ownership around the world. Journal of Finance 57, 1471-517.

Lee, S. and D. Mullineaux, 2004. Monitoring, financial distress and the structure of commercial lending syndicates. Financial Management 33, 107-130. 
Leland, H. and D.Pyle, 1977. Informational asymmetries, financial structure, and financial intermediation. Journal of Finance 32, 371-387.

McNamara G. and P. Vaaler, 2000. The influence of competitive positioning and rivalry in emerging market risk assessment. Journal of International Business Studies 31, 337347.

Moody's 2000. Bankruptcy and ratings: A leveraged finance approach for Europe. UK versus France and Germany.

Moody's 2004. Measuring the Quality and consistency of corporate ratings across regions.

Moody's 2006. Request for comment on: Probability of default ratings and loss given default assessments for corporate obligors in Europe, Middle East and Africa:

Recommended Framework.

Morck, R., Shleifer, A. and R. Vishny, 1988. Management ownership and corporate performance: An empirical analysis. Journal of Financial Economics 20, 293-315. Morck, R., Yeung, B. and W. Yu, 2000. The information content of stock markets: Why do emerging markets have synchronous stock price movements? Journal of Financial Economics 58, 215-260.

Purda, L. 2007. Stock market reaction to anticipated versus surprise rating changes. Journal of Financial Research forthcoming.

Rajan, R. and L. Zingales, 1998. Financial dependence and growth. American Economic Review 88, 559-586.

Rajan, R. and L. Zingales, 2001. Financial system, industrial structure, and growth. Oxford Review of Economic Policy 17, 467-482.

Stulz, R. 1988. Managerial control of voting rights: Financing policies and the market for corporate control. Journal of Financial Economics 20, 25-54.

Vaaler, P., Schrange, B. and S. Block, 2005. Counting the investor vote: political business cycle effects on sovereign bond spreads in developing countries. Journal of International Business Studies 36, 62-88. 
Table 1: Descriptive Statistics

Panel A: Median Leverage, Coverage and Profitability by Country

\begin{tabular}{lccc}
\hline Country & Debt to Capital & $\begin{array}{c}\text { Interest } \\
\text { Coverage }\end{array}$ & $\begin{array}{c}\text { Return on Assets } \\
\text { (ROA) }\end{array}$ \\
\hline Canada & 41.98 & 3.40 & 2.53 \\
France & 73.76 & 4.08 & 0.58 \\
Germany & 74.04 & 3.04 & 0.19 \\
Japan & 72.39 & 4.10 & 0.64 \\
United Kingdom & 58.04 & 4.49 & 2.17 \\
United States & 49.94 & 4.39 & 3.35 \\
\hline
\end{tabular}

Panel B: Summary Statistics by Financial System Orientation

\begin{tabular}{|c|c|c|c|}
\hline & Market-Based & Bank-Based & $\begin{array}{c}\text { Test Stat } \\
\text { Market }=\text { Bank }\end{array}$ \\
\hline \multicolumn{4}{|l|}{ Sample Medians } \\
\hline Long-term Debt to Capital & 39.79 & 40.88 & $\begin{array}{c}1.87 \\
(0.17)\end{array}$ \\
\hline Debt to Capital & 49.43 & 72.22 & $\begin{array}{c}205.13 * * * \\
(0.00)\end{array}$ \\
\hline Return on Assets & 3.25 & 0.59 & $\begin{array}{c}656.82 * * * \\
(0.00)\end{array}$ \\
\hline Market Capitalization (000's of US\$) & $2,809.20$ & $3,440.35$ & $\begin{array}{c}8.43 * * * \\
(0.00)\end{array}$ \\
\hline Interest Coverage & 4.34 & 4.00 & $\begin{array}{l}5.22 * * \\
(0.02)\end{array}$ \\
\hline Rating Assignment $(\mathrm{Aaa}=6, \mathrm{~B}=1)$ & 3 & 4 & $\begin{array}{c}27.09 * * * \\
(0.00)\end{array}$ \\
\hline Observations & 4,542 & 1,701 & \\
\hline
\end{tabular}

$*, * *$, and $* * *$ indicate significance at the ten, five, and one percent levels respectively.

Note: Table 1 provides median values for various financial characteristics across the sample firms when firms are categorized according to either country of origin (Panel A) or financial system type (Panel B). Financial statement variables presented in Panel B act as the principle controls used in the empirical tests. Leverage measures and return on assets are presented in percentage form. For example, return on assets is calculated as net income divided by total assets multiplied by 100 . Interest coverage is calculated as the sum of operating income after depreciation plus interest expense divided by interest expense. The third column in the panel provides test statistics for whether the median values vary significantly for the market versus bank sample. Probabilities associated with these statistics are presented in parenthesis. 
Table 2: Median Firm Financial Characteristics by Rating Assignment and Financial System Orientation

\begin{tabular}{|c|c|c|c|c|}
\hline & Full Sample & Market-Based & Bank-Based & $\begin{array}{c}\text { Test Stat } \\
\text { Market }=\text { Bank }\end{array}$ \\
\hline \multicolumn{5}{|l|}{ Aaa $=6$} \\
\hline LTD to Capital & 32.11 & 16.87 & 77.21 & $16.59 * * *(0.00)$ \\
\hline Debt to Capital & 40.701 & 36.34 & 54.71 & $5.76^{* *}(0.02)$ \\
\hline ROA & 1.349 & 12.94 & 0.33 & $84.72 * * *(0.00)$ \\
\hline Mkt. Cap. & $29,711.89$ & $60,833.85$ & $5,228.58$ & $22.42 * * *(0.00)$ \\
\hline Int. Coverage & 16.704 & 21.33 & 3.89 & $24.48 * * *(0.00)$ \\
\hline \multicolumn{5}{|l|}{$A \mathbf{a}=5$} \\
\hline LTD to Capital & 30.26 & 28.15 & 45.35 & $15.38 * * *(0.00)$ \\
\hline Debt to Capital & 50.10 & 46.45 & 61.27 & $4.11 * *(0.04)$ \\
\hline ROA & 1.56 & 5.45 & 0.76 & $73.56 * * *(0.00)$ \\
\hline Mkt. Cap. & $15,394.68$ & $17,227.21$ & $11,862.91$ & $4.27 * *(0.04)$ \\
\hline Int. Coverage & 7.90 & 10.54 & 4.26 & $58.29 * * *(0.00)$ \\
\hline \multicolumn{5}{|l|}{$A=4$} \\
\hline LTD to Capital & 35.16 & 35.30 & 34.43 & $0.30 \quad(0.59)$ \\
\hline Debt to Capital & 48.55 & 47.12 & 60.33 & $17.31 * * *(0.00)$ \\
\hline ROA & 2.82 & 3.75 & 0.80 & $178.97 * * *(0.00)$ \\
\hline Mkt. Cap. & $5,845.76$ & $5,736.22$ & $6,304.82$ & $0.92 \quad(0.34)$ \\
\hline Int. Coverage & 5.87 & 5.81 & 6.46 & $0.90 \quad(0.34)$ \\
\hline \multicolumn{5}{|l|}{$\mathbf{B a a}=\mathbf{3}$} \\
\hline LTD to Capital & 39.56 & 39.59 & 39.41 & $0.04 \quad(0.85)$ \\
\hline Debt to Capital & 50.64 & 45.60 & 72.64 & $212.66 * * *(0.00)$ \\
\hline ROA & 2.20 & 3.36 & 0.59 & $352.36 * * *(0.00)$ \\
\hline Mkt. Cap. & $2,260.29$ & $2,250.72$ & $2,293.32$ & $0.05 \quad(0.82)$ \\
\hline Int. Coverage & 4.19 & 4.21 & 4.14 & $0.20 \quad(0.66)$ \\
\hline \multicolumn{5}{|l|}{$\mathbf{B a}=\mathbf{2}$} \\
\hline LTD to Capital & 47.38 & 46.99 & 49.93 & $0.88 \quad(0.80)$ \\
\hline Debt to Capital & 58.18 & 52.68 & 105.48 & $80.67 * * *(0.00)$ \\
\hline ROA & 2.02 & 2.88 & 0.36 & $102.41 * * *(0.00)$ \\
\hline Mkt. Cap. & 839.69 & 750.16 & $1,079.21$ & $20.71 * * *(0.00)$ \\
\hline Int. Coverage & 3.37 & 3.43 & 3.17 & $2.70 *(0.10)$ \\
\hline \multicolumn{5}{|l|}{$\mathbf{B}=\mathbf{1}$} \\
\hline LTD to Capital & 64.86 & 64.88 & 64.72 & $0.07 \quad(0.80)$ \\
\hline Debt to Capital & 72.22 & 70.14 & 112.95 & $27.41 * * *(0.00)$ \\
\hline ROA & -0.16 & -0.30 & -0.01 & $0.32 \quad(0.57)$ \\
\hline Mkt. Cap. & 222.65 & 187.69 & 512.74 & $51.02 * * *(0.00)$ \\
\hline Int. Coverage & 2.08 & 2.05 & 2.19 & $1.64 \quad(0.20)$ \\
\hline
\end{tabular}

$*, * *$, and $* * *$ indicate significance at the ten, five, and one percent levels respectively.

Note: Table 2 presents median firm characteristics when the sample is categorized by rating assignments. Financial variables are as defined in Table 1. Columns two and three provide medians when firms are further divided according to their countries' financial system orientation. The fourth column provides test statistics (with probabilities in parentheses) for differences in median values across financial system type. 
Table 3: Country Financial System and Legal Characteristics

Panel A: Summary of Country Characteristics (Year = 1998)

\begin{tabular}{llcccccc}
\hline Country & System & $\begin{array}{c}\text { Credit } \\
\text { (\% GDP) }\end{array}$ & $\begin{array}{c}\text { Stock Mkt. Size } \\
\text { (\% GDP) }\end{array}$ & $\begin{array}{c}\text { Creditor } \\
\text { Protection } \\
\text { Max =4 }\end{array}$ & $\begin{array}{c}\text { Property } \\
\text { Rights } \\
\text { Max }=30\end{array}$ & $\begin{array}{c}\text { Inst. } \\
\text { Effective } \\
\text { Max }=10\end{array}$ & $\begin{array}{c}\text { Judicial } \\
\text { Transparency } \\
\text { Max =5 }\end{array}$ \\
\hline Canada & Market & 94.70 & 88.10 & 1 & 28.63 & 8.5 & 4 \\
France & Bank & $100.84^{\dagger}$ & 66.78 & 0 & 27.89 & 7.4 & 4 \\
Germany & Bank & 142.99 & 49.68 & 3 & 28.60 & 8.5 & 5 \\
Japan & Bank & 240.92 & 64.74 & 2 & 27.88 & 7.4 & 4 \\
Netherlands & Market & $123.57^{\dagger}$ & 151.99 & 2 & 29.33 & 9.3 & 5 \\
New Zealand & Bank & 108.31 & 45.67 & 3 & 28.98 & 9.3 & 5 \\
U. K. & Market & 122.28 & 166.55 & 4 & 28.44 & 9.3 & 5 \\
United States & Market & 81.76 & 153.78 & 1 & 27.61 & 7.4 & 4 \\
\hline
\end{tabular}

${ }^{\dagger}$ Represents the 1997 value due to unavailability of 1998 data.

Panel B: Pairwise Correlation Between Country Characteristics for 1993 - 2001

\begin{tabular}{lccccccc}
\hline & $\begin{array}{c}\text { Financial } \\
\text { System }\end{array}$ & $\begin{array}{c}\text { Domestic } \\
\text { Credit }\end{array}$ & $\begin{array}{c}\text { Stock } \\
\text { Market }\end{array}$ & $\begin{array}{c}\text { Creditor } \\
\text { Protection }\end{array}$ & $\begin{array}{c}\text { Property } \\
\text { Rights }\end{array}$ & $\begin{array}{c}\text { Inst. } \\
\text { Effectiveness }\end{array}$ & $\begin{array}{c}\text { Judicial } \\
\text { Transparency }\end{array}$ \\
\hline Financial System & 1.00 & & & & & & \\
Domestic Credit & $0.46^{* * *}$ & 1.00 & & & & & \\
Stock Market & $-0.71^{* * *}$ & -0.11 & 1.00 & & & & \\
Creditor Protect. & 0.00 & 0.17 & 0.14 & 1.00 & & & \\
Property Rights & -0.15 & $-0.24^{*}$ & -0.36 & $0.45^{* * *}$ & 1.00 & & \\
Inst. Effectiveness & $-0.31^{* *}$ & $-0.33^{* *}$ & 0.21 & $0.64^{* * *}$ & $0.78^{* * *}$ & 1.00 & \\
Judicial Transp. & 0.00 & -0.18 & 0.05 & $0.82^{* * *}$ & $0.76^{* * *}$ & $0.77^{* * *}$ & 1.00 \\
\hline
\end{tabular}

$*, * *$, and $* * *$ indicate significance at the ten, five, and one percent levels respectively.

Note: Panel A of Table 3 provides country characteristics related to financial system and legal environment for countries within the sample. Where these characteristics are timevarying, data from 1998 is used for illustrative purposes. Panel B of the table provides the pairwise correlation between these characteristics across the entire sample time period, 1993 - 2001. Correlations are qualitatively similar when examined for individual years. 
Table 4: Influence of Financial System on Credit Ratings

Ordered Probit Model with the Dependent Variable = Rating Assignment

\begin{tabular}{|c|c|c|c|c|}
\hline & Base Case & Bank Dummy & $\begin{array}{c}\text { Domestic } \\
\text { Credit }\end{array}$ & $\begin{array}{c}\text { Domestic Credit } \\
\text { and Stock } \\
\text { Market } \\
\end{array}$ \\
\hline \multicolumn{5}{|l|}{ Fin. System Indicator } \\
\hline Bank Dummy & & $\begin{array}{c}0.387 * * * \\
(0.00)\end{array}$ & & \\
\hline Domestic Credit & & & $\begin{array}{c}0.002 * * * \\
(0.00)\end{array}$ & $\begin{array}{c}0.002 * * \\
(0.03)\end{array}$ \\
\hline Stock Market Size & & & & $\begin{array}{c}-0.001 * \\
(0.10) \\
\end{array}$ \\
\hline \multicolumn{5}{|l|}{ Controls } \\
\hline LT Debt/Capital & $\begin{array}{c}-0.005^{* * *} \\
(0.00)\end{array}$ & $\begin{array}{c}-0.003^{*} \\
(0.08)\end{array}$ & $\begin{array}{c}-0.004^{*} \\
(0.07)\end{array}$ & $\begin{array}{c}-0.004^{*} \\
(0.07)\end{array}$ \\
\hline Total Debt/Capital & $\begin{array}{c}0.001 \\
(0.23)\end{array}$ & $\begin{array}{l}-0.000 \\
(0.70)\end{array}$ & $\begin{array}{l}-0.000 \\
(0.86)\end{array}$ & $\begin{array}{l}-0.000 \\
(0.85)\end{array}$ \\
\hline ROA & $\begin{array}{c}-0.000 \\
(1.00)\end{array}$ & $\begin{array}{l}0.006 \\
(0.21)\end{array}$ & $\begin{array}{l}0.004 \\
(0.46)\end{array}$ & $\begin{array}{l}0.004 \\
(0.40)\end{array}$ \\
\hline Interest Coverage 1 & $\begin{array}{c}0.181 * * * \\
(0.00)\end{array}$ & $\begin{array}{c}0.182 * * * \\
(0.00)\end{array}$ & $\begin{array}{c}0.192 * * * \\
(0.00)\end{array}$ & $\begin{array}{c}0.190^{* * * *} \\
(0.00)\end{array}$ \\
\hline Interest Coverage 2 & $\begin{array}{l}0.021 \\
(0.34)\end{array}$ & $\begin{array}{l}0.025 \\
(0.28)\end{array}$ & $\begin{array}{l}0.025 \\
(0.29)\end{array}$ & $\begin{array}{l}0.024 \\
(0.31)\end{array}$ \\
\hline Interest Coverage 3 & $\begin{array}{c}0.046^{* * * *} \\
(0.00)\end{array}$ & $\begin{array}{c}0.040 * * * \\
(0.01)\end{array}$ & $\begin{array}{c}0.043 * * * \\
(0.01)\end{array}$ & $\begin{array}{c}0.042 * * * \\
(0.01)\end{array}$ \\
\hline Interest Coverage 4 & $\begin{array}{l}0.000 \\
(0.94)\end{array}$ & $\begin{array}{l}-0.001 \\
(0.75)\end{array}$ & $\begin{array}{r}-0.001 \\
(0.65)\end{array}$ & $\begin{array}{l}-0.002 \\
(0.63)\end{array}$ \\
\hline Market Capitalization & $\begin{array}{c}0.679 * * * \\
(0.00)\end{array}$ & $\begin{array}{c}0.678 * * * \\
\quad(0.00)\end{array}$ & $\begin{array}{c}0.681 * * * \\
(0.00)\end{array}$ & $\begin{array}{c}0.685 * * * \\
(0.00)\end{array}$ \\
\hline Year & $\begin{array}{c}-0.055^{* * *} \\
(0.00)\end{array}$ & $\begin{array}{c}-0.071^{* * *} \\
(0.00)\end{array}$ & $\begin{array}{c}-0.078^{* * *} \\
(0.00)\end{array}$ & $\begin{array}{c}-0.063^{* * *} * \\
(0.00)\end{array}$ \\
\hline Industry Controls & Yes & Yes & Yes & Yes \\
\hline $\mathrm{N}$ & 4,306 & 4,306 & 4,202 & 4,202 \\
\hline Pseudo $\mathrm{R}^{2}$ & 0.31 & 0.31 & 0.31 & 0.31 \\
\hline
\end{tabular}

$*, * *$, and $* * *$ indicate significance at the ten, five, and one percent levels respectively.

Note: Table 4 provides the estimated coefficients from an ordered probit model with Moody's rating as the dependent variable. Independent variables include financial, year and industry group controls. Financial variables are as defined in Table 1. Coefficients for the 13 industry groups are not provided to conserve space. Columns 2 through 4 introduce proxies for whether a country's financial system is bank or market oriented. Robust standard errors are used to account for multiple observations from the same firm. 
Table 5: Exploring the Influence of the Legal System

Ordered Probit Model with the Dependent Variable = Rating Assignment

\begin{tabular}{|c|c|c|c|}
\hline & $\begin{array}{c}\text { Legal Base } \\
\text { Case }\end{array}$ & $\begin{array}{c}\text { Bank } \\
\text { Dummy }\end{array}$ & $\begin{array}{c}\text { Alternative } \\
\text { Legal Measures }\end{array}$ \\
\hline \multicolumn{4}{|l|}{ Fin. System Indicator } \\
\hline Bank Dummy & & $\begin{array}{c}0.335^{* * *} \\
(0.00)\end{array}$ & $\begin{array}{c}0.417 * * * \\
(0.00)\end{array}$ \\
\hline \multicolumn{4}{|l|}{ Legal Factors } \\
\hline Creditor Protection & $\begin{array}{c}0.140^{* *} \\
(0.03)\end{array}$ & $\begin{array}{l}0.032 \\
(0.63)\end{array}$ & \\
\hline Property Rights & $\begin{array}{l}0.186 \\
(0.14)\end{array}$ & $\begin{array}{l}0.184 \\
(0.15)\end{array}$ & \\
\hline Inst. Effectiveness & & & $\begin{array}{l}0.050 \\
(0.65)\end{array}$ \\
\hline Judicial Transparency & & & $\begin{array}{l}0.244 \\
(0.22)\end{array}$ \\
\hline \multicolumn{4}{|l|}{ Controls } \\
\hline LT Debt/Capital & $\begin{array}{c}-0.005^{* * *} \\
(0.01)\end{array}$ & $\begin{array}{c}-0.003 * \\
(0.08)\end{array}$ & $\begin{array}{l}-0.002 \\
(0.27)\end{array}$ \\
\hline Total Debt/Capital & $\begin{array}{c}0.001 \\
(0.51)\end{array}$ & $\begin{array}{l}-0.000 \\
(0.75)\end{array}$ & $\begin{array}{l}-0.001 \\
(0.33)\end{array}$ \\
\hline $\mathrm{ROA}$ & $\begin{array}{l}0.001 \\
(0.79)\end{array}$ & $\begin{array}{l}0.006 \\
(0.23)\end{array}$ & $\begin{array}{l}0.005 \\
(0.35)\end{array}$ \\
\hline Interest Coverage 1 & $\begin{array}{c}0.191 * * * \\
(0.00)\end{array}$ & $\begin{array}{c}0.187 * * * \\
(0.00)\end{array}$ & $\begin{array}{c}0.170 * * * \\
(0.00)\end{array}$ \\
\hline Interest Coverage 2 & $\begin{array}{c}0.024 \\
(0.29)\end{array}$ & $\begin{array}{c}0.026 \\
(0.26)\end{array}$ & $\begin{array}{c}0.043^{*} \\
(0.08)\end{array}$ \\
\hline Interest Coverage 3 & $\begin{array}{c}0.046^{* * * *} \\
(0.00)\end{array}$ & $\begin{array}{c}0.041 * * * \\
(0.01)\end{array}$ & $\begin{array}{l}0.028^{*} \\
(0.08)\end{array}$ \\
\hline Interest Coverage 4 & $\begin{array}{c}-0.000 \\
(0.89)\end{array}$ & $\begin{array}{c}-0.001 \\
(0.73)\end{array}$ & $\begin{array}{l}0.001 \\
(0.70)\end{array}$ \\
\hline Market Capitalization & $\begin{array}{c}0.675 * * * \\
(0.00)\end{array}$ & $\begin{array}{c}0.676^{* * *} \\
(0.00)\end{array}$ & $\begin{array}{c}0.679 * * * \\
(0.00)\end{array}$ \\
\hline Year & $\begin{array}{c}-0.070^{* * *} \\
(0.00)\end{array}$ & $\begin{array}{c}-0.077 * * * \\
(0.00)\end{array}$ & $\begin{array}{c}-0.066^{* * * *} \\
(0.00)\end{array}$ \\
\hline Industry Controls & Yes & Yes & Yes \\
\hline $\mathrm{N}$ & 4,306 & 4,306 & 3,564 \\
\hline Pseudo $\mathrm{R}^{2}$ & 0.31 & 0.31 & 0.31 \\
\hline
\end{tabular}

$*, * *$, and $* * *$ indicate significance at the ten, five, and one percent levels respectively.

Note: Table 5 provides the estimated coefficients from an ordered probit model with Moody's rating as the dependent variable. Independent variables include financial, year and industry group controls. Financial variables are as defined in Table 1. Coefficients for the 13 industry groups are not provided to conserve space. The table examines whether higher ratings continue to be associated with firms from bank-oriented financial systems even after characteristics of the legal environment are taken into account. Robust standard errors are used to account for multiple observations from the same firm. 
Table 6: Influence of Ease of Monitoring and Corporate Governance Concerns Ordered Probit Model with the Dependent Variable = Rating Assignment

\begin{tabular}{|c|c|c|c|c|}
\hline & $\begin{array}{c}\text { Bank } \\
\text { Dummy }\end{array}$ & Tangibility & $\begin{array}{c}\text { Tangibility and } \\
\text { R\&D }\end{array}$ & $\begin{array}{c}\text { Governance } \\
\text { Concerns }\end{array}$ \\
\hline Bank Dummy & $\begin{array}{c}0.387 * * * \\
(0.00)\end{array}$ & $\begin{array}{c}0.406^{* * *} \\
(0.00)\end{array}$ & $\begin{array}{c}0.450^{* * *} \\
(0.00)\end{array}$ & $\begin{array}{c}0.561 * * * \\
(0.00)\end{array}$ \\
\hline \multicolumn{5}{|l|}{ Ease of Monitoring } \\
\hline PP\&E & & $\begin{array}{c}1.362 * * * \\
(0.00)\end{array}$ & $\begin{array}{c}1.634 * * * \\
(0.00)\end{array}$ & \\
\hline R\&D & & & $\begin{array}{c}-3.616^{* *} \\
(0.03)\end{array}$ & \\
\hline \multicolumn{5}{|l|}{ Governance Concerns } \\
\hline Closely held Shares & & & & $\begin{array}{c}-0.504 * * \\
(0.04)\end{array}$ \\
\hline Political Connections & & & & $\begin{array}{l}0.308 \\
(0.24)\end{array}$ \\
\hline \multicolumn{5}{|l|}{ Controls } \\
\hline LT Debt/Capital & $\begin{array}{c}-0.003 * \\
(0.08)\end{array}$ & $\begin{array}{c}-0.005 * * * \\
(0.01)\end{array}$ & $\begin{array}{c}-0.007 * * \\
(0.03)\end{array}$ & $\begin{array}{l}-0.002 \\
(0.36)\end{array}$ \\
\hline Total Debt/Capital & $\begin{array}{l}-0.000 \\
(0.70)\end{array}$ & $\begin{array}{l}0.001 \\
(0.27)\end{array}$ & $\begin{array}{r}-0.000 \\
(0.91)\end{array}$ & $\begin{array}{l}-0.002 \\
(0.24)\end{array}$ \\
\hline ROA & $\begin{array}{l}0.006 \\
(0.21)\end{array}$ & $\begin{array}{l}0.002 \\
(0.67)\end{array}$ & $\begin{array}{l}0.006 \\
(0.38)\end{array}$ & $\begin{array}{l}0.006 \\
(0.27)\end{array}$ \\
\hline Interest Coverage 1 & $\begin{array}{c}0.182 * * * \\
(0.00)\end{array}$ & $\begin{array}{c}0.201 * * * \\
(0.00)\end{array}$ & $\begin{array}{c}0.144 * * * \\
(0.00)\end{array}$ & $\begin{array}{c}0.174 * * * \\
(0.00)\end{array}$ \\
\hline Interest Coverage 2 & $\begin{array}{l}0.025 \\
(0.28)\end{array}$ & $\begin{array}{l}0.039^{*} \\
(0.10)\end{array}$ & $\begin{array}{c}0.062 * * \\
(0.04)\end{array}$ & $\begin{array}{l}0.044^{*} \\
(0.07)\end{array}$ \\
\hline Interest Coverage 3 & $\begin{array}{c}0.040^{* * *} \\
(0.01)\end{array}$ & $\begin{array}{c}0.051 * * * \\
(0.00)\end{array}$ & $\begin{array}{c}0.049 * * \\
(0.02)\end{array}$ & $\begin{array}{c}0.046^{* * * *} \\
(0.01)\end{array}$ \\
\hline Interest Coverage 4 & $\begin{array}{l}-0.001 \\
(0.75)\end{array}$ & $\begin{array}{l}-0.001 \\
(0.88)\end{array}$ & $\begin{array}{l}-0.004 \\
(0.38)\end{array}$ & $\begin{array}{l}-0.003 \\
(0.39)\end{array}$ \\
\hline Market Capitalization & $\begin{array}{c}0.678^{* * * *} \\
(0.00)\end{array}$ & $\begin{array}{c}0.690 * * * \\
(0.00)\end{array}$ & $\begin{array}{c}0.826^{* * *} \\
(0.00)\end{array}$ & $\begin{array}{c}0.682 * * * \\
(0.00)\end{array}$ \\
\hline Year & $\begin{array}{c}-0.071 * * * \\
(0.00)\end{array}$ & $\begin{array}{c}-0.070 * * * \\
(0.00)\end{array}$ & $\begin{array}{c}-0.090^{* * * *} \\
(0.00)\end{array}$ & $\begin{array}{c}-0.074 * * * \\
(0.00)\end{array}$ \\
\hline Industry Controls & Yes & Yes & Yes & Yes \\
\hline $\mathrm{N}$ & 4,306 & 4,070 & 2,284 & 3,669 \\
\hline Pseudo $\mathrm{R}^{2}$ & 0.31 & 0.33 & 0.39 & 0.32 \\
\hline
\end{tabular}

$*, * *$, and $* * *$ indicate significance at the ten, five, and one percent levels respectively.

Note: Table 6 provides the estimated coefficients from an ordered probit model with Moody's rating as the dependent variable. Independent variables include financial, year and industry group controls. Financial variables are as defined in Table 1. Coefficients for the 13 industry groups are not provided to conserve space. The table introduces asset tangibility (measured by property, plant and equipment and R\&D expenses both scaled by assets) and corporate governance concerns (measured by the proportion of closely held shares and political connections) as possible influences on credit rating assignment. Robust standard errors are used to account for multiple observations from the same firm. 